\title{
Bonding together the pasts: the mining of lime in Brazilian shell mounds
}

\author{
Marília Oliveira CALAZANS
}

\begin{abstract}
This article seeks to understand the links between mining and archaeology in shell mounds of coastal Brazil, vastly used as lime sources since the early colonization. The shell mounds are the most ancient traces of the occupation of the Brazilian coast and many of them are extinct, because of the mining, which converted their shells into the cement of colonial buildings. Between devastation and cooperation, there are connected activities that were revealed by the scientific papers, published in the nineteenth century, and by the history of the public management of those sites through the twentieth century.
\end{abstract}

Key-words: Shell mounds (Sambaqui), mining, lime, Brazil, industrial archaeology, life-history.

\section{Archaeological sites and mineral deposits}

Until the archaeology protected the shell mounds, covering them with its scientificity, those sites were mere traces of the barbaric indigenous. Or a good profit source, a site where it was possible to obtain the shells needed to produce lime. The very image of a shell mound might be unknown by most of the people. However, the end of many of them is a very famous heritage: the colonial buildings all over the coast of the country. Many of the buildings constructed in the colonial period in Brazil has lime, used as cement, mixed with sand and whale fat. In other words, buildings made from shell mounds. This paper aims to suggest an archaeological pathway to connect shell mounds and the houses made with their by-products.

In Brazil, the shell mounds have a special name: sambaqui. This word has a Tupi (a native language) origin and means literally shell (taba) mound ( $k i$ ). Despite of the Tupi origin, sambaqui was a word chosen by Brazilian scientists, in the late $19^{\text {th }}$ century, to name those sites. From that moment on, sambaqui would be the word to designate the archaeological phenomena abundant in the Brazilian coast. Local and foreigner scientists were interested in investigating shell mounds, under the new archaeological paradigms. We are talking about a double genesis: archaeology as a science, and Sambaqui, as a scientific fact. ${ }^{1}$

\footnotetext{
1 We used the concept of genesis as in Ludwik Fleck, Gênese e desenvolvimento de um fato cientifico. 1.ed. Trad. Georg Otte, Mariana Camilo de Oliveira. (Belo Horizonte: Fabrefactum), 2010.
} 
Sambaqui itself is a generic concept. It names the human-made shell accumulations, among other organic materials, such as earth, sand and bones. They are aged approximately 1000 to $8000 \mathrm{AP}^{2}$ Nowadays, the sambaquis left have survived to erosion, climatic changes, variation of sea level, and mainly to the lime exploitation, which has consumed uncountable sites along the coast and (in a few cases) in fluvial contexts.

Even if it was not unanimous, the word and the concept of sambaqui was a solid reference among scientists. In the following excerpts, it is showed and analysed by Karl Von Kozeritz and Carl Hartt, both prominent foreigner archaeologists, who were researching the theme in Brazil.

„It is a series of mounds of oysters, which I hesitate to name sambaqui, because they are small and short and they cover an area of 5 to 10 square meters. Whereas, the thing we name sambaqui are high hills.

On the other hand, the oysters' mounds of Conceição are extraordinarily similar to the Kjokkjenmoddings of Denmark."

„[Kitchen midden] is an English word, which means an accumulation of kitchen waste. If these words were not so difficult to assimilate, it would be convenient to adopt them within the Portuguese language, which has no precise equivalent. The word sambaqui used in this chapter's title is defective, because it does not necessarily involve the idea of the human action. It is applied to any shells accumulation, either natural or artificial."

The other names used to stand for sambaquis have in common the fact they are very descriptive of the external aspect of this type of archaeological site that occurs in several coasts all over the world. In Danish, they are called Kjokkenmoedding. In French, amas de coquilles. Kayzuka in Japanese and so on. All those names might be translated into English as "shell mound". There were other names to the phenomenon during the colonial and imperial period

2 These ages were obtained by means of dating with analysis of Carbon 14, according to several works that we consulted. In the nineteenth century, the period whose documents are central to this research, the projection of ages depended on estimates based on archaeological data such as the sophistication of artefacts (in ascending order: chipping, polishing, ceramics, metal), stratigraphic layers analysis and theories of American settlement, intertwined with other data. Craniometry and the analysis of the decomposition state of the shells were also used to estimate the age of the sambaquis. On the subject, there was no consensus, however. Scholars have risked ages ranging from three hundred years to pre-Flood. Marília Oliveira Calazans, Os sambaquis e a arqueologia no Brasil do século XIX. (Dissertação Mestrado em História Social, Universidade de São Paulo), 2016.

3 Karl Von Koseritz, „Sambaquis da Conceição do Arroio.” Revista do Instituto Histórico e Geográfico Brasileiro. Rio de Janeiro, vol. XLVII, parte I, 1884, 179-180.

4 Carlos Hartt, „Contribuições para a ethnologia do valle do Amazonas." Archivos do Museu Nacional, Rio de Janeiro, vol. 6, 1885, 2. 
in Brazil, according to a documentary series that we analysed here. Ostreiras (oyster's mound) and berbigueiros (cockle's mound), both due to the type of the shell that composed the site. Casqueiros or concheiros were more generic. Also, we have the mina de sernamby (mine of clam).

None of those designations appeals to the archaeological characteristics of sambaquis. Out of all of those terms, the last one (mine) is the only one which might have a meaning beyond the descriptivism. The word mine does not describe any (pre)historic characteristic either. However, it shows us what the social role of sambaqui was: source of shells, which would be burnt to make the necessary lime to colonial buildings, to pave roads, among other uses. It was in the State of Para where the name mine was registered (the sites were called Mina de Apicuns, Mina do Capitão Clarindo, for instance). Nevertheless, the industrial and economic exploitation of sambaqui is pointed out by many documents of the $19^{\text {th }}$ century, the subjects of our research.

Ferreira Penna, the founder of the Museu Paraense, was the author of the first scientific bulletin about the Sambaqui of Para. He followed oral information from the locals, and travelled along the Pirabas River. He looked for sambaqui all over the region, and he found many extinct or in the process of extinction sites due to the work of the "clams loaders". It seems that human bones were milled with the shells to obtain the lime. However, not every time, as Ferreira Penna wrote:

„In 1875, the sambaqui workers found a human skeleton in a rude clay pot, which was buried among the shells. Captain Clarindo ordered to keep it; after several days, the Vicar of Bragança knew about that fact, he went to the place, collected the bones and, when he came back, he ordered to bury them in the public cemetery."

In the São Paulo's coast, the Swedish naturalist Albert Loefgren has also witnessed the industrial exploitation of sambaqui.

„When, for the first time, we crossed the arm of the sea separating the island of S. Vicente from the mainland, in the month of May 1875, we passed near the island of the Casqueiro. At that time, there was a lot of life there. A large group of workers moved there in full activity, revolving the surface and filling carcasses down to the seashore, near furnaces that laid thick clouds of smoke and where flat boats received loading full bags.

Admired with this industrial movement on a small island, we asked our companion: "What establishment is that?"

"It's a lime factory", he told us.

5 Domingos S. Ferreira Penna, „Breve notícia sobre os sambaquis do Pará.” Archivos do Museu Nacional, vol. 1, 1876, 90. 
"Lime?", we asked, "This island is then formed of a calcareous rock?"

"No," he replied, "they extract the lime from the oyster shells of a large sambaqui that covers most of the island."

Records from this period link the sambaquis to lime production abound. This means that before the historical and archaeological meaning, the sambaquis were conceived as source of mineral wealth of its proprietors, from which they were so often baptized. The industrial activity, while at the same time undermining archaeological remains, collaborated with scientific investigations. These activities were not exclusive, on the contrary, coexisted.

Pioneering investigators followed in the nineteenth century the traces of the lime industrial activity to find the sambaquis. They got information, artefacts, and research materials when apparently sambaquis were not completely exhausted. Conde de La Hure clearly expressed this relationship when he wrote "[...] M. Francisco de Souza, l'obligeant propriétaire de ce conchyliosite est disposé à y laisser faire toutes les recherches qu'on jugera utiles. ${ }^{7}$ Ferreira Penna also pointed out that "[...] The Lieutenant Mattos Muniz, chief resident of Sao Joao, and a very honest man, told me before several witnesses that in a restinga, near the village, he had found some bones more than a year ago, including a skull still with hair. When caught, the skull was almost powdered."

Despite the idiosyncratic association between industrial and archaeological expeditions, it is evident that the researchers expressed concern. The extinction of sambaqui would imply the irreparable loss of information about the "prehistory" of the Brazilian territory. Albert Loefgren's work is, as the author announced, in the first place an attempt to record what was left of those sites on the coast of São Paulo, given the risk of extinction that was imminent. Benedicto Calixto, even not being convinced of the anthropic nature of sambaquis, was another ardent defender of their preservation. ${ }^{9}$ It is worth mentioning the cartographic work of both, published in São Paulo journals, which consisted of valuable contributions to the archaeology, geography and history of science.

A German zoologist and director of the Paulista Museum, Herman Von Ihering, claimed his authority to challenge the studies that occurred in previous decades. In 1903, he published in the pages of the Revista do Instituto Histórico e

6 Albert Loefgren, „Os Sambaquis de São Paulo.” Boletim da Comissão Geográfica e Geológica do Estado de São Paulo, n. 9, 1893, 13.

7 "M. Francisco de Souza, the helpful owner of this shell mound is willing to allow any research we deem useful". Conde de La Hure, Considérations sommaires sua l'origine des amas de coquillages de la côte du Brésil, Dona Francisca. 10 mar 1865. IHGB, Lata 15, doc. 9, 23.

8 Penna, „Breve notícia sobre os sambaquis”, 88.

9 Benedito Calixto, „Algumas notas e informações sobre a situação dos sambaquis de Itanhaen e de Santos." Revista do Museu Paulista. São Paulo, vol. VI, 1904, 490-518. 
Geográfico de São Paulo an article in which he affirmed that sambaqui had been formed under water or other natural ways. His argument was centred especially on the characteristic of the shells and the form of their agglomeration. He was not able to elaborate equally robust explanation for the fact that there were artefacts and human bones within sambaqui, although he has rehearsed some hypotheses. The chipped stones would naturally have been swept away by streams, and the human skeletons resulted from drowning. Von Ihering was definitely a solitary voice in defending the thesis of the natural origin of sambaqui. Nevertheless, relevance this publication reverberated through all subsequent decades, when so many archaeological texts mistakenly stated that the great issue of the nineteenth century revolved around the artificial or natural origin of sambaqui. ${ }^{10}$

Anyway, it is important to our argument that, although there were disagreements regarding the archaeological nature of sambaqui, the abovementioned authors were categorical in defending the protection of these sites. This is how von Ihering ended his text:

„I understand that the sambaquis, instead of losing interest, on the contrary, exalt it, since they have not only an archaeological, but also geological importance. They represent in this sense documents of high value, whose systematic destruction constitutes an act of vandalism, against which it is time to protest energetically. I call for the support of the Instituto Histórico e Geográfico de São Paulo in order that the patriotic government of the State may propose the necessary measures for their conservation." ${ }^{\prime 1}$

Decades after the controversy, it was still possible to glimpse some conciliatory vision for the "archaeology vs. industry" conflict that was formed around the sambaqui. In the years of 1960, it appeared with the one that may have been the greatest defender of these sites, Paulo Duarte, who marked:

„Needless to say, this progress has been detrimental to civilization, or rather to culture, to Brazil's scientific heritage, to its cultural reserves and even to its international reputation. Because of the increasing commercial and industrial interest, the intensive destruction of the sambaqui, with mechanical excavators, in a shameful contempt for its scientific use, has in recent times taken on not only frightening but also depressing, humiliating and sacrilegious proportions.

$[\ldots]$

${ }^{10}$ This idea reverberated from the seminal publication of Angyone Costa. Costa, Angyne. Introdução à Arqueologia brasileira (etnografia e história), (São Paulo: Companhia Editora Nacional).

${ }^{11}$ Herman von Ihering, „A origem dos sambaquis.” Revista do Instituto Histórico e Geográfico de São Paulo, São Paulo, vol. VIII, 1903, 457. 
The most pitiful aspect of our sambaquis devastation lies in the fact that their scientific exploitation can be done without any detriment to the industrial interest. This has not yet been understood, unconsciously or purposely, neither by those who exploit them, nor by the public powers, who have never watched them. Scientific research is slow, there is no doubt, but what it removes from the sambaqui does not represent $3 \%$ of its content, whose limestone can be totally used for industry or commerce." 12

From a modern perspective, this conciliation would be impracticable. When Paulo Duarte pondered it, it was considered that only the artefact and skeleton vestiges would serve for research. From them, you would get a lot of information, such as dating, lithic technologies, food, tools, for example. The essential content of sambaqui, the shells (which would make up $97 \%$ of the material of sambaqui, according to Duarte), could be discarded or destined to the production of lime, fertilizer, feed, among other purposes.

To endorse this reasoning it is necessary to admit that the shells of the molluscs that make up the sambaqui do not provide any information. Recent research disassembles the conciliatory proposition in several aspects and through different approaches. Just to cite a few examples, the faunistic portion of sambaqui was analysed in theses on feeding and symbolic / artefact use of these traces. ${ }^{13}$ From the shells, it is also possible to identify which species of molluscs migrated along European ships to the Brazilian coast, since the construction of the sambaqui was an activity somehow abandoned centuries before the European colonial invasion. ${ }^{14}$

The conservation of sambaqui is also important for the establishment of settlement patterns and inter-site analyses. ${ }^{15}$ Since archaeological intervention itself is a disturbance, there are authors who are concerned with developing less invasive methods of research. ${ }^{16}$

${ }_{12}$ Paulo Duarte, O sambaqui: visto através de alguns sambaquis, São Paulo, IPH-USP, 1968, 20-21.

${ }^{13}$ Respectively, Levy Figuti, "O homem pré-histórico, o molusco e o sambaqui: considerações sobre a subsistência dos povos sambaquieiros.” Revista do Museu de Arqueologia e Etnologia, 1993, 3; Manoel M. B. Gonzalez. Tubarões e raias na pré-história do litoral de São Paulo. (Tese Doutorado em Arqueologia Museu de Arqueologia e Etnologia, Universidade de São Paulo), 2005.

${ }^{14}$ Rosa Cristina Corrêa Luz de Souza, Sálvio Henrique Calazans \& Edson Pereira Silva, "Impacto das espécies invasoras no ambiente aquático." Ciência e cultura, 61, 2009, 1. http:// cienciaecultura.bvs.br/scielo.php?script=sci arttext\&pid=S0009-67252009000100014\&lng= en\&nrm=iso (Accessed September 15, 2016).

${ }^{15} \mathrm{MaDu}$ Gaspar, Sambaqui: arqueologia do litoral brasileiro. (Rio de Janeiro: Jorge Zahar), 2004.

${ }^{16}$ Tiago Attorre, Por uma Arqueologia Marginal: As ocupações peri-sambaquieiras no entorno do sambaqui da Figueirinha II, Jaguaruna-SC, examinadas através do radar de penetração de solo. (Dissertação Mestrado em Arqueologia, Universidade de São Paulo), 2015. 
Nevertheless, from a historical perspective linked to this series of documents, it can be affirmed that the identity of sambaqui remained divided between archaeology and industry. Another example of this misfortune is the Code of Mines which, from 1934, protected and regulated the exploitation of mineral deposits. This was the first law at the national level that protected sambaqui from predatory action, albeit indirectly. In legal terms, the monumentality of sambaqui remained indifferent until 1961, when decree-law 3924 disposed on these sites as vestiges of the paleoamerindian culture. Its exploitation for economic and industrial purposes would be conditioned to the endorsement of SPHAN (Service of National Historical and Artistic Heritage), an institution inaugurated in 1937.

The Getúlio Vargas government's bid to put the mining of the national territory under the rule of law had a plan side effect that was certainly unpredictable. Published in 1938, issued by the Ministry of Agriculture, the book Concheiros naturais e Sambaquis, written by the geologist Othon Henry Leonardos, is still today one of the most complete works on sambaqui in Brazil. Also, it is considered a conceptual landmark on the subject. From the suggestion of Leonardos, it would be called "sambaqui" only the anthropic formations of archaeological interest. For all other conglomerations of shells, he reserved the name "natural shell mounds". ${ }^{17}$ These added variables inaugurated a new understanding about sambaqui. The mining question was in the past from then on, and it was about time.

\section{Towards the history of sambaqui mining and the lime industry}

The sambaquis accumulated, from the social relations that surrounded them, the memory of all these temporalities. First, they were monuments of an ancient coastal population, built by the obstinate action of the oldest inhabitants of this coast for millennia. In a new phase, the sambaqui resisted centuries, composing the landscape that had been dominated by other populations. These witnessed the arrival of the Portuguese. From then on, the shell mounds were other populations which witnessed the proof of the indigenous indifference and indolence. The sites became mines, from which the chemical produced in Brazil was obtained: lime. Brazil becomes independent; the "century of science" has the emperor as patron. Then, the sambaquis were born to science as an archaeological phenomenon. This materiality is the persistent element throughout the narrative, which floats across the most diverse contexts.

${ }^{17}$ Othon Henry Leonardos, Concheiros Naturais e Sambaquis. Avulso n. 37. (Rio de Janeiro: Ministério da Agricultura), 1938. 


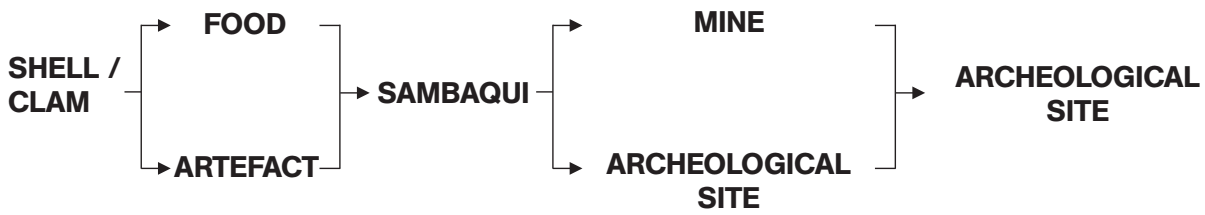

Fig. 1. Sambaqui's life cycle, from th0e archaeological perspective of the life-history of the artifacts.

To consider that mining is now and back then a part of the life-history of sambaqui does not mean to relativize the importance of its preservation. ${ }^{18}$ On the contrary, its visibility within the history of architecture and mining in Brazil in the colonial period may fill an important gap in the narratives about the site. The records of the mining activity are the only about shell mounds in this period, as it seems. They also show somehow the reinsertion of the sambaquis into the landscape, in its archaeological context, millennia after the period of coastal occupation by sambaqui populations. This period concerns the occupation by indigenous people with ceramist tradition and, some centuries later, European settlers.

As Donald Harvesty rehearsed in his theoretical reflection on a case study in Nevada, United States, mining archaeology explores the social structure of mining, through material vestiges of technological systems, landscapes and social formations based on these activities. Among the material remains, there were buildings, structures, ruins and historical documents. According to the author, "the most imposing expression of the mining past may be architecture". ${ }^{19}$ In the case of sambaquis, there is an extensive documentation that expresses the association between architecture and the mining of these sites.

The classic text of Fernao Cardim, Tratados da Terra e Gente do Brasil, dates back to the end of the $16^{\text {th }}$ century. In it, the priest historian comments on the origin of the lime that built the Jesuit College of Salvador, among others:

„Prior, the natural Indians came to the sea because of the oysters. They took so many of them that they left behind mounds of shells, and the nucleus, they took in order to eat during the year and over those mounds, along the years, large and big trees grown and the Portuguese found some of them and each

\footnotetext{
${ }^{18}$ We took the concept "Life-history" as presented in: Chris Gosden e Yvonne Marchall. “The cultural biography of objects." World Archaeology, 1999, 31, 2, http://www.jstor.org/ stable/125055 (accessed September 15, 2016).

${ }^{19}$ Donald L. Hardesty, Mining Archaeology in the American West: A view from the Silver State. (Lincon: University of Nebraska Press), 2010, 12.
} 
day they find others again, and from these shells they make lime and from one single mount they built part of the Bahia's School and many other buildings and [the shell mounds] are not extinct yet." ${ }^{20}$

Another historian, Fr. Gaspar da Madre de Deus, described centuries later the exploration of sambaquis in the Captaincy of Sao Vicente, from a perspective quite similar to that of Cardim, relating it to the construction of buildings in the Captaincy. He wrote in his Memoirs: "From those shells of the mussels that the Indians ate, they have done all the lime of the buildings of this Captaincy since its foundation and hitherto. And later, the mounds of oysters of Santos, Sao Vicente, Conceicao, Iguape and Cananea will finish". ${ }^{21}$ A few decades later, in 1866, the eminent naturalist, Richard Francis Burton, would confirm his testimony in a publication in Europe, only adding a dose of optimism:

„Of these kjökken-möddings there are in Santos Bay about twenty, besides many down the coast at Iguapa, Cauanen, and their maritime hauts southwards. Some are of great size. On December $3^{\text {rd }}$, in company with Senor Juan Baptista da Silva Bueno, and Messrs. Glennie and Miller of this city, I visited a deposit in the 'Ilha de Casceiro,' to the north-west of Santos. It contains three mounds, one of which is about 200 feet high, and about 2800 feet each way. The oysters in question form a conglomeration (of which a specimen is forwarded) in blocks which reach a ton weight. They have supplied the country with lime for the last three centuries, and will yet last for a long time."22

The Fortress of Óbidos, in Pará, in turn, was the target of the records of Charles Hartt, but before that, those of Ferreira Penna and Arcipreste Noronha.

„[... there is a great sambaqui on an island bordering that city, called Itanduya, and that the lime employed in the construction of the fort of Óbidos came from a sambaqui situated at the place called Mondongo, on the western side of the Trombetas River [...]. Noronha says that "Between Vila Viçosa (Cametá) and the channel of Limoeiro are dilated mines of cockles and marine shells, to which the name of Sernamby is given, from which a considerable quantity of lime is made, which is another branch of commerce from this village." 23

${ }^{20}$ Fernão Cardim, Tratados da terra e gente do Brasil. (Rio de Janeiro: Editores J. Leite \& Cia.), 1925, 92.

${ }^{21}$ Madre de Deus, Gaspar da Friar, Memórias para a história da Capitania de São Vicente. (Lisboa: Typografia da Academia), 1797, 20.

${ }^{22}$ Richard Francis Burton, „On a kjokkenmodding of Santos, Brazil.” Journal of the Anthropological Society of London, Londres, vol. 4, 1866, cxciii-cxciv.

${ }^{23}$ Hartt, „Contribuições para a ethnologia,” 6. 
The informants, in this way, testified to the researchers the path of the shells of sambaquis to the cement of the colonial buildings. These records should not be underestimated in the composition of the local economic history. Joining them to other documentary testimonies, such as property records and receipts, light can be shed on the structure of the industry that has undermined one of the most precious archaeological remains of the Brazilian territory.

Work and technique were issues reserved for the enslaved population, as the Brazilian elite despised manual labour, Shozo Motoyama said. ${ }^{24}$ Well, slave labour was probably associated with all industrial exploitation of the sambaquis, in the nineteenth century and earlier, and to a certain extent, with archaeology. The paragraph of Count de La Hure, written in the 1860s, is perhaps the best description for the engraving that Jean-Baptiste Debret had produced decades earlier, illustrating a lime oven in Rio de Janeiro. ${ }^{25}$

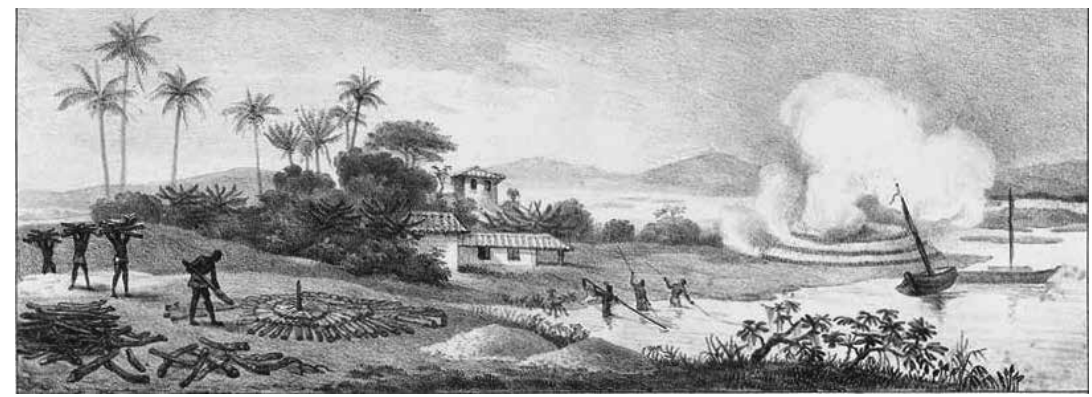

Fig. 2. Four à chaux [lime oven], Jean-Baptiste Debret.

„Au moment de ma visite, des esclaves travaillaient à l'extraction des coquilles, leur travail mit à découvert, en ma présence, un squelette humain entier, dans la position repliée que présentent tous les squelettes provenant de corps inhumés. [...] Les coquilles extraites du conchyliosite sont portées à la mer, ou elles subissent un lavage, pendant lequel on extrait et l'on jette à l'eau tous les corps étrangers qui s'y rencontrent en foule haches, couteaux, débris de potières, ossements, etc. Tempus edax, homo edacior." [Time is hunger, men are ever more]. ${ }^{26}$

${ }^{24}$ Shozo Motoyama (Org.), Prelúdio para uma história: Ciência e Tecnologia no Brasil. (São Paulo: Edusp; Fapesp, 2004), 18. This mentality, according to Motoyama, provoked a divorce between theory and practice, an indispensable pair for scientific action. 2004, p. 87.

${ }^{25}$ Four à chaux, Apud. Soraya Vita, Fernando J. Luna e Simone Teixeira. "Descrições de técnicas da química na produção de bens de acordo com os relatos dos naturalistas viajantes no Brasil colonial e imperial”. Química Nova: set-out 2007, 30. (accessed September 14, 2016). http:// $\underline{\text { www.scielo.br/scielo.php?script }=\text { sci arttext\&pid=S0100-40422007000500055\&lng=en\&nr }}$ $\underline{m}=$ iso

${ }^{26}$ De La Hure, Considérations sommaires sua l'origine, 26-27. 
A contemporary of Debret, Auguste de Saint-Hilaire, emphasized the unhealthiness of the work of shell extraction:

„Near some of the islands we saw black people who, dipped in water up to the waist, gathered shells of shellfish. As there are no calcareous rocks in the vicinity of Rio de Janeiro, they replaced them with lime from the shells. To prepare the lime, large cones are raised alternately; one on top of the other, thick layers of shells and firewood, and a fire is set. The work of harvesting clams in the water is the most unfavourable to the health of blacks, and often causes them dangerous diseases."27

In the province of São Paulo, where sambaquis received the illustrious visit of the emperor Dom Pedro II in 1876, slave labour was also recorded by Carlos Rath, here commented by Abílio Marques, in a specific work on the sambaquis of the coast of São Paulo.

"Going to the shell mound, they examined [the commission formed by Carlos Rath and the emperor D. Pedro II] "the graduation of the layers of alluvion, verifying that they were 24 feet of height above the sambaquis. At this point, we are no longer working on oyster shells; the black men who worked in this service left a large clod, an agglomeration of oysters and earth, which contained the human bones of an individual with some ornaments and stone weapons. "So encompassed that they formed a single mass the size of a meter or more." 28

This technology of lime manufacture is also embraced by the perspective of industrial archaeology, a branch of the discipline that consists of the "study of the causes, characteristics and consequences of industrialization, based on the identification, registration, preservation and interpretation of the vestiges of the industry in its cultural and historic context". The incipient industrialization in Brazil of the colonial period has, therefore, an important record in the branch of the manufacture of the lime. Information on history of science of technique and work, which are contained in the most recent layers of the sambaquis, as anticipated by Loefgren:

„A layer of excellent vegetable land of 38 centimetres thick, medium term covers this sambaqui. In this layer, several pieces of tiles and dishes of old Portuguese dish were found. The presence of these relatively modern objects is undoubtedly due to the establishment of some ranch for the rest of the workers occupied in extracting the bark for the lime factory, of which there are

\footnotetext{
${ }^{27}$ Auguste Saint-Hilaire, Viagem pelas províncias do Rio de Janeiro e Minas Gerais. (Belo Horizonte: Itatiaia), 1975, 18.

${ }^{28}$ Abílio S. Marques, "As ostreiras de Santos e os kiokken-moddings da Dinamarca." Revista brasileira, 1880, 6.
} 
still vestiges about 200 meters away, on the slope of the hill of the Side of West." 29

\section{Final considerations}

The successive re-appropriations of the past represented / contained in a sambaqui-like site attest that the shell mounds are archaeological monuments that testify much more than a "prehistoric" past. From a certain perspective, the biography of sambaquis crosses different periods of history, amalgamating evidences of the populations that constructed them and / or used them.

The "creative destruction" of sambaquis can be understood beyond the vandalism, as Von Ihering and Paulo Duarte have pointed out before. ${ }^{30}$ These are also the vestiges of the techniques of construction and material resources, since the shells were alternatives to the absence of calcareous rocks in coastal areas. Witnesses of the expansion of capitalism, the population density and the growing intervention of the metropolis in Brazil, slave labour, Jesuit presence and its consequent and irreversible social changes.

The interest in the Brazilian archaeological and industrial archaeological heritage, synthesized by the binomial preservation / destruction of the sambaquis, can still, and this is an issue of interest to everyone, incite a reflection on the limits of development, intervention, exploitation of resources and our relation to these ancestral heritages.

\section{Rezumat}

Prin acest articol autorul încearcă să înțeleagă legăturile dintre minerit și arheologie, în depunerile de cochilii ale Braziliei de coastă, folosite în mare măsură ca surse de calcar de la începutul colonizării. Aglomerațiile de cochilii sunt cele mai vechi urme ale ocupației teritoriului brazilian și multe dintre ele au dispărut din cauza mineritului, care le-a transformat scoicile în cimentul clădirilor coloniale. Între devastare și cooperare există activități conexe pe care am încercat să le dezvăluim prin lucrările științifice publicate în secolul al XIX-lea și prin istoria gestionării publice a acestor situri în secolul al XX-lea.

Cuvinte-cheie: Aglomerații cochilii (Sambaqui), minerit, var, Brazilia, arheologie industrială, istoria vieții.

${ }^{29}$ Loefgren, „Os Sambaquis de São Paulo”, 26.

${ }^{30}$ The term was coined by the Austrian economist Joseph Schumpeter, which industrial archaeology recovered. 